\title{
PERANAN LEMBAGA PEMBERDAYAAN MASYARAKAT KELURAHAN (LPMK) DALAM MENINGKATKAN PARTISIPASI MASYARAKAT PADA PEMBANGUNAN DI KELURAHAN MAMASA
}

\author{
Damaiwana ${ }^{1}$ \\ ${ }^{1}$ Prodi Ilmu Pemerintahan, Fakultas Ilmu Sosial dan Ilmu Pemerintahan \\ Universitas Al Asyariah Mandar \\ Email: Damaiwana-22@gmail.com \\ Ahmad Saleh ${ }^{1}$ \\ ${ }^{1}$ Prodi Ilmu Pemerintahan, Fakultas Ilmu Sosial dan Ilmu Pemerintahan \\ Universitas Al Asyariah Mandar \\ Email:ahmadmahoya@gmail.com
}

\begin{abstract}
The purpose of this study was to identify and describe the role of the Village Community Empowerment Institution (LPMK) in accommodating and channeling community aspirations in the development of Mamasa Village, Mamasa Regency. The method to be used is qualitative research with descriptive research type. The results showed that the role of LPMK in accommodating and channeling community aspirations was still not optimal. LPMK did not schedule the right time to hold a meeting with each head of the ward, so the aspirations by each head of the ward were not effective.
\end{abstract}

\begin{abstract}
ABSTRAK
Tujuan penelitian ini untuk mengetahui dan mendeskripsikan peran Lembaga Pemberdayaan Masyarakat Desa (LPMK) dalam menampung dan menyalurkan aspirasi masyarakat dalam pembangunan Desa Mamasa Kabupaten Mamasa. Metode yang akan digunakan adalah penelitian kualitatif dengan jenis penelitian deskriptif. Hasil penelitian menunjukkan bahwa peran LPMK dalam menampung dan menyalurkan aspirasi masyarakat masih belum maksimal. LPMK tidak menjadwalkan waktu yang tepat untuk mengadakan pertemuan dengan masing-masing kepala lingkungan, sehingga penyampaian aspirasi yang dilakukan oleh masing-masing kepala lingkungan tidak efektif.
\end{abstract}

Kata Kunci: LPMK, Partisipasi, Aspirasi.

\section{PENDAHULUAN}

Pada hakikatnya tujuan pembangunan suatu Negara dilaksanakan adalah untuk mensejahterakan masyarakat, sesuai dengan pembukaan Undang-Undang Dasar 1945 yang dinyatakan bahwa tujuan pembangunan 
Nasional bangsa Indonesia adalah melindungi segenap bangsa dan seluruh tumpah darah Indonesia, memajukan kesejahteraan umum, mencerdaskan kehidupan bangsa, serta ikut melaksanakan ketertiban dunia, untuk mewujudkan tujuan tersebut dilaksanakan pembangunan Nasional, yaitu pembangunan negara Indonesia seutuhnya dan pembangunan masyarakat seluruhnya.

Keberhasilan pembangunan Nasional terukur dari meratanya pembangunan sampai ke daerah-daerah maka dengan sendirinya akan terwujud pembangunan Nasional secara menyeluruh. Keikutsertaan masyarakat setempat juga merupakan hal penting dalam pembangunan di pedesaan dan kelurahan.

Hal ini tentu ada keterikatan emosional terhadap lingkungan sekitarnya. Tentu saja masyarakat mengetahui kekayaan potensi serta kemampuan yang dimiliki oleh daerahnya dan disamping itu pula masyarakat merupakan salah satu penggerak pembangunan di daerahnya.

Program pembangunan kelurahan adalah suatu usaha-usaha jangka panjang yang mempunyai tujuan meningkatkan pembangunan pada suatu sektor tertentu untuk mencapai beberapa proyek kelurahan. Program juga dapat dipahami sebagai kegiatan sosial yang teratur mempuyai tujuan yang jelas dan khusus serta dibatasi oleh tempat dan waktu tertentu, program pembangunan dibatasi atas proyek-proyek pembangunan yang dilakukan melalui upaya-upaya secara sadar dan terencana yang ada di kelurahan.

Pelaksanaan kegiatan Lembaga Pemberdayaan Masyarakat diawali dari musyawarah yang dilakukan pihak Lembaga Pemberdayaan Masyarakat Kelurahan (LPMK) bersama setiap kepala lingkungan yang dipelopori oleh pihak kelurahan sebagai pihak yang menjadi fasilitator pembangunan. Selanjutnya hasil musyawarah yang telah dilakukan maka akan dibawa ke musyawarah pembangunan tingkat kelurahan, dimana disini akan dibahas mengenai pembangunan kelurahan yang akan dibangun. Dalam musyawarah yang akan dilakukan di kelurahan ini seluruh aspirasi yang ada akan dibahas. Selanjutnya dalam musyawarah ini akan dibahas pembangunan mana yang akan menjadi prioritas dalam pembangunan nantinya, sehingga akan dapat menghindari pembangunan yang hanya akan menguntungkan kepentingan kelompok tertentu.

Kurang maksimalnya peranan Lembaga Pemberdayaan Masyarakat Kelurahan (LPMK) dalam hal ini menampung dan menyalurkan aspirasi masyarakat LPMK di kelurahan Mamasa belum menjalankan perannya sesuai dengan peran dan fungsinya sebagai penggerak dalam pembangunan, dapat dilihat dalam penentuan jadwal rapat bersama setiap kepala lingkungan yang tidak jelas maka untuk penyampaian aspirasi masyarakat kurang efektif. Pihak 
LPMK juga kurang maksimal dalam hal meningkatkan partisipasi masyarakat karena berdasarkan penelitian bahwa LPMK kurang proaktif terhadap pembangunan fisik di kelurahan Mamasa.

\section{METODE PENELITIAN}

Penelitian yang akan digunakan adalah penelitian Kualitatif dengan tipe penelitian deskriptif. Tipe penelitian deskriptif yaitu suatu tipe penelitian yang bertujuan untuk memberikan gambaran secara sistematis, faktual dan akurat mengenai data yang ada dilapangan tentang partisipasi masyarakat dalam proses perencanaan pembangunan di Kelurahan Mamasa kabupaten Mamasa.

Penelitian kualitatif memiliki karakteristik dengan mendeskripsikan suatu keadaan yang sebenarnya, tetapi laporannya bukan sekedar bentuk laporan suatu kejadian tanpa suatu interpretasi ilmiah serta memahami atau memperoleh pemahaman mengenai fenomena atau gejala yang diangkat untuk diteliti secara mendalam. (radjab mansyur, bahan ajar metode penelitian kualitatif, jurusan sosiologi fisip uh, 2014:18) Dasar penelitian yang digunakan yaitu observasi dan wawancara secara langsung, yang bertujuan untuk mengumpulkan data dan informasi dari sejumlah informan yang dianggap dapat memberikan informasi yang berhubungan dengan maslah penelitian.

\section{HASIL PENELITIAN}

Peranan Lembaga Pemberdayaan Masyarakat Kelurahan (LPMK) dalam Menampung dan Menyalurkan Aspirasi Masyarakat pada Pembangunan di Kelurahan Mamasa

Berdasarkan Peraturan Pemerintah Nomor 73 Tahun 2005 tentang Kelurahan, dijelaskan pada pasal 10 bahwa pembentukan lembaga kemasyarakatan dikelurahan atas prakarsa masyarakat melalui musyawarah dan mufakat. Tujuan pembentukan suatu lembaga kemasyarakatan untuk memelihara dan melestarikan nilai-nilai gotong royong dan kekeluargaan merupakan sendi-sendi utama dalam kehidupan bermasyarakat di Indonesia.

Peranan lembaga kemasyarakatan dalam membantu tugas lurah meliputi; membantu lurah dalam pelaksanaan urusan pemerintahan, membantu lurah dalam pelaksanaan urusan pembangunan, membantu lurah dalam pelaksanaan urusan sosial kemasyarakatan dan pemberdayaan.

Secara umum Lembaga Pemberdayaan Masyarakat Kelurahan (LPMK) dalam menampung dan menyalurkan aspirasi masyarakat menyiapkan sarana seperti penyediaan:

1. Kotak saran 
Dalam upaya mempermudah, menampung segala aspirasi, keluhan maupun saran dari masyarakat, pihak Lembaga Pemberdayaan Masyarakat Kelurahan (LPMK) menggunakan pola penyediaan kotak saran atau pengaduan.

Kotak saran merupakan tempat menampung surat berupa usulan dan saran bagi masyarakat. Dengan adanya kotak saran diharapkan agar masyarakat juga mau menyampaikan aspirasinya terhadap pelayanan dan pembangunan di Kelurahan. Langkah ini merupakan bentuk komitmen kelurahan untuk menyukseskan program pembangunan di kelurahan. Setiap aspirasi masyarakat maupun keluhan dari warga masyarakat melalui kotak saran tersebut akan ditampung oleh Lembaga Pemberdayaan Masyarakat Kelurahan (LPMK) dan diperhatikan sebagaimana mestinya. Meskipun kotak saran yang akan disediakan bersifat terbuka kepada masyarakat secara luas, namun warga yang menyampaikan keluhankeluhan maupun saran akan dirahasiakan identitasnya.

\section{Kuesioner}

Kuesioner merupakan daftar yang berisi pertanyaan-pertanyaan yang dijawab dan dikerjakan oleh responden. Kuesioner ini digunakan untuk mengetahui tanggapan responden terhadap pertanyaan yang diajukan. Dengan adanya kuesioner responden mudah dalam memberikan jawaban, karena jawaban telah tersedia akan membutuhkan waktu yang singkat dalam menjawabnya.

Tujuan kuesioner yaitu untuk memperoleh data yang relevan sesuai dengan yang akan dicapai. Kuesioner yang dibuat juga untuk memecahkan masalah penelitian. Maka dari itu kuesioner yang dibuat harus menggunakan bahasa yang dapat dimengerti oleh masyarakat agar masyarakat mudah dalam menjawab kuesioner yang diberikan. Dalam menampung dan menyalurkan aspirasi masyarakat dilakukan melalui cara membagikan kuesioner kepada masyarakat setiap lingkungan dan kemudian masyarakat akan diberikan arahan cara mengisi kuesioner yang diberikan.

\section{Rapat}

Adapun cara yang dilakukan masyarakat kelurahan Mamasa dalam menyampaikan aspirasinya yaitu melalui rapat yang dihadiri oleh setiap kepala lingkungan dimana masyarakat menyampaikan keluhannnya kepada setiap kepala lingkungan masing-masing, kemudian setiap kepala lingkungan menyampaikan aspirasi masyarakat ke Lembaga Pemberdayaan Masyarakat Kelurahan (LPMK).

Jadwal yang dilakukan oleh Lembaga Pemberdayaan Masyarakat Kelurahan (LPMK) untuk mengadakan rapat tidak jelas dan tidak menentu. 
Sehingga saran dan keluhan yang disampaikan oleh masyarakat kepada kepala lingkungannya masing-masing tidak jelas kapan akan disampaikan kepada ketua Lembaga Pemberdayaan Masyarakat Kelurahan (LPMK).

Hal ini berdasarkan hasil wawancara bersama kepala lingkungan yang mengatakan bahwa:

"Tidak ada kepastian kapan jadwal rapat yang diumumkan oleh ketua Lembaga Pemberdayaan Masyarakat Kelurahan (LPMK), sehingga saran dan keluhan dari masyarakat hanya sekedar ditampung dan belum tersalurkan" (Wawancara, 22 Januari 2019)

Hal ini juga dipertegas oleh salah satu kepala lingkungan Mamasa yang mengatakan bahwa:

"Biasanya ketua Lembaga Pemberdayaan Masyarakat Kelurahan (LPMK) tidak jelas dalam mengadakan rapat. Namun, dalam tahun ini mengadakan rapat saat mendekati jadwal Musrenbang. Jadi dalam tahun ini Lembaga Pemberdayaan Masyarakat Kelurahan (LPMK), hanya mengadakan rapat satu kali dalam satu tahun" (Wawancara, 23 Januari 2019)

Berdasarkan hasil wawancara dengan kepala lingkungan terlihat bahwa Lembaga Pemberdayaan Masyarakat Kelurahan (LPMK) tidak efektif dalam menampung aspirasi masyarakat karena tidak ada kejelasan jadwal rapat yang dilaksanakan oleh Lembaga Pemberdayaan Masyarakat Kelurahan (LPMK).

Setelah melakukan rapat, kemudian pihak Lembaga Pemberdayaan Masyarakat Kelurahan (LPMK) berkoordinasi ke kelurahan tepatnya di Kasi pemberdayaan dan kesejahteraan masyarakat yang kemudian akan dibahas lanjut pada rapat musrenbang kelurahan.

Hal ini dijelaskan dalam wawancara bersama ketua Lembaga Pemberdayaan Masyarakat Kelurahan (LPMK) yang mengatakan bahwa:

"Dalam menampung aspirasi masyarakat kami mengadakan rapat yang diwakili setiap kepala lingkungan” (Wawancara, 21 Januari 2019).

Hal ini juga dipertegas oleh salah satu kepala lingkungan yang mengatakan bahwa:

"Setelah saya mendapat pengaduan atau saran dari masyarakat mengenai masalah pembangunan yang ada di lingkungan, kemudian saya menyampaikan kepada ketua Lembaga Pemberdayaan Masyarakat Kelurahan (LPMK) saat rapat" (Wawancara, 23 Januari 2019).

Berdasarkan hasil wawancara diatas bahwa masyarakat dalam menyampaikan keluhan yang dialami mengenai masalah pembangunan di kelurahan Mamasa, mereka mengadukan ke kepala lingkungannya masing- 
masing. Setelah adanya saran dan pengaduan dari masyarakat, kepala lingkungan membawa hasil pengaduan dalam rapat yang dilakukan oleh Lembaga Pemberdayaan Masyarakat Kelurahan (LPMK). Kemudian hasil dari rapat yang dilakukan oleh Lembaga Pemberdayaan Masyarakat Kelurahan (LPMK) bersama setiap kepala lingkungan, ketua Lembaga Pemberdayaan Masyarakat Kelurahan (LPMK). berkoordinasi ke kantor kelurahan yang dikoordinasikan kepada Kasi Pemberdayaan dan Kesejahteraan Masyarakat, dan kemudian akan di bahas lanjut pada rapat musrenbang.

Lembaga pemberdayaan masyarakat kelurahan mempunyai fungsi menampung dan menyalurkan aspirasi masyarakat; penyusun rencana, pelaksana dan pengelola pembangunan serta pemanfaat, pelestarian dan pengembangan hasil-hasil pembangunan secara partisipatif; dan penumbuhkembangan dan penggerak prakarsa dan partisipasi, serta swadaya gotong royong masyarakat.

Peranan Lembaga kemasyarakatan terkhusus Lembaga Pemberdayaan Masyarakat Kelurahan (LPMK) di kelurahan Mamasa dalam menampung dan menyalurkan aspirasi masyarakat terutama dibidang pembangunan yang dimana di kelurahan Mamasa memiliki program pembangunan yang telah di musyawarahkan pada musrenbang kelurahan. Hal tersebut senada dengan pernyataan Lurah Mamasa:

"Yang dilakukan dalam menampung dan menyalurkan aspirasi masyarakat melalui musrenbang kelurahan, jadi yang diperlukan kehadirannya yaitu tokoh masyarakat, tokoh agama, tokoh pemuda, kepala lingkungan, dan juga masyarakat ikut serta musrenbang kelurahan, karena merekalah yang menyampaikan aspirasi apa saja yang mereka anggap perlu di bangun di lingkungannya, program pembangunan yang di laksanakan secara bertahap misalnya yang mereka usulkan semua hampir sama yaitu pembuatan jalan tani, pembuatan drainase, pembuatan jamban keluarga dan penerangan lampu jalan yang merupakan prioritas di lingkungannya masingmasing" (Wawancara, 21 Januari 2019).

Berdasarkan hasil wawancara di atas, bahwa program utama yang di jalankan oleh Lembaga Pemberdayaan Masyarakat Kelurahan (LPMK) seperti pembuatan jalan tani, pembuatan drainase, pembuatan jamban keluarga dan penerangan lampu jalan. Hal tersebut dikarenakan di kelurahan Mamasa sebagian besar masyarakatnya memiliki mata pencaharian pokok sebagai petani,sehingga dibutuhkan pembangunan jalan untuk melancarkan aktivitas pertanian, juga di kelurahan Mamasa di beberapa lingkungan mengeluhkan saluran drainase,masih kurangnya jamban keluarga dan tidak adanya penerangan lampu jalan dibeberapa lingkungan yang merupakan prioritas bagi masyarakat di kelurahan Mamasa. 
Peranan Lembaga Pemberdayaan Masyarakat Kelurahan (LPMK) dalam Meningkatkan Partisipasi Masyarakat pada Pembangunan fisik di Kelurahan Mamasa.

Peranan Lembaga Pemberdayaan Masyarakat Kelurahan (LPMK) dalam meningkatkan partisipasi masyarakat merupakan hal yang penting dalam mengikutsertakan masyarakat dalam melaksanakan program pembangunan yang telah di programkan karena LPMK merupakan penggerak kegiatan ini di Kelurahan Mamasa.

Partisipasi masyarakat merupakan sesuatu yang harus ditumbuhkembangkan dalam proses pembangunan, namun di dalam praktiknya, tidak selalu diupayakan sungguh-sungguh. Di pihak lain, tumbuh dan berkembangnya partisipasi masyarakat dalam proses pembangunan, mensyaratkan adanya kepercayaan yang diberikan oleh "pemerintah" kepada masyarakatnya untuk terlibat secara aktif di dalam proses pembangunan. (Aprilia Theresia, Krisnha dkk,

Pembangunan Berbasis Masyarakat, 2015, hlm. 206). Untuk mengetahui peran Lembaga Pemberdayaan Masyarakat di Kelurahan Mamasa Kecamatan Tanete Riattang Timur, ada beberapa fungsi dan peranannya yaitu fungsi lembaga pemberdayaan masyarakat kelurahan dalam meningkatkan partisipasi masyarakat adalah sebagai fasilitator dan dinamisator bagi pembangunan wilayah kelurahan. Berikut peranan LPMK di Kelurahan Mamasa:

1. Lembaga Pemberdayaan Masyarakat Kelurahan sebagai Fasilitator

Peran LPMK sebagai fasilitator di Kelurahan adalah memfasilitasi segala aktivitas masyarakat mengenai program pembangunan yang direncanakan kemudian untuk dilaksanakan. Sebagai fasilitator LPMK selain mengusulkan pembangunan juga melakukan pendampingan terhadap perangkat-perangkat RT dan RW di Kelurahan. Peran LPMK di Kelurahan Mamasa memang terlihat sebagai fasilitator di dalam upaya menyusun rencana pembangunan hal ini ditandai dengan program LPMK di dalam melakukan aktivitas rapat antara perangkat kelurahan yang mewakili warga masyarakat dengan pemerintah kecamatan. Agar dapat menjadi fasilitator yang baik ada beberapa hal yang dapat dilihat yaitu:

a. Masyarakat Ikut Merencanakan Pembangunan.

Masyarakat yang ikut merencanakan pembangunan pada masing-masing kelurahan merupakan bentuk tanggungjawab masing-masing kelurahan untuk menumbuhkan rasa peduli tentang program yang akan dilaksanakan di 
kelurahan mereka demi tercapainya pembangunan yang bersifat fisik yang dibutuhkan masyarakat setempat.

Masyarakat boleh ikut merencanakan pembangunan yang akan dilaksanakan kelurahan mereka dan juga harus bertanggungjawab dengan program yang telah mereka usulkan dalam musrenbang tingkat kelurahan dan seterusnya. Hal senada disampaikan oleh kepala lingkungan Mamasa :

"Dalam merencanakan pembangunan yang akan dilaksanakan di kelurahan ini memang masyarakat diikut sertakan dalam mengusulkan pembangunan yang menjadi prioritas di lingkungan masing-masing karena disini kelurahan Mamasa ada lima lingkungan dan di usulkan di musrenbang kelurahan". (Wawancara, 22 Januari 2019)

Hal ini juga dipertegas oleh ketua lingkungan yang mengatakan bahwa:

"Masyarakat diikut sertakan dalam usulan pembangunan dan mereka juga harus bertanggung jawab atas pembangunan yang telah mereka usulkan di kelurahan Mamasa". (Wawancara, 24 Januari 2019)

Berdasarkan hasil wawancara dengan salah seorang informan selaku kepala lingkungan Mamasa dan kepala lingkungan mengatakan bahwa masyarakat yang aktif seperti yang dikatakan kepala lingkungan di dalam merencanakan pembangunan akan mempercepat kemajuan pembangunan yang akan dilaksanakan karena mereka tidak perlu lagi di perintah terlebih dahulu demi kemajuan pembangunan di kelurahan Mamasa.

Masyarakat yang aktif di kelurahan Mamasa ternyata tidak semua yang memiliki keaktifan yang sama karena berdasarkan informasi dari masyarakat yang lain yang menyatakan bahwa:

"Iya saya tahu kalau ada musrenbang di kelurahan, tapi saya tidak ikut dalam rapat itu karena saya ikut saja dengan apa keputusan dari pihak kelurahan" (Wawancara, 22 Januari 2019)

Berdasarkan hasil wawancara dengan salah seorang informan selaku masyarakat di kelurahan Mamasa bahwa masyarakat dikelurahan Mamasa kurang peduli terhadap pembangunan yang akan dilaksanakan karena mereka hanya mengikuti apa hasil keputusan musrenbang tanpa ikut serta dalam musrenbang kelurahan tersebut. Terkait dengan pernyataan dari masyarakat seperti di atas dapat kita lihat bahwa partisipasi masyarakat di kelurahan Mamasa masih kurang kesadarannya dari masing-masing individu, apalagi dengan zaman sekarang gotong royong dan kebersamaan sudah sangat berkurang, karena mereka sibuk dengan urusannya masing-masing.

Hal ini berdasarkan wawancara bersama salah seorang masyarakat, yang mengatakan bahwa: 
"Wajar kalau partisipasi masyarakat disini kurang karena menurut saya setiap orang memiliki kepentingan masingmasing. Seperti sibuk mencari pengahasilan untuk memenuhi kebutuhan keluarganya" (Wawancara, 22 Januari 2019)

Adapun faktor yang menjadi penghambat yaitu kurangnya kesadaran atau kemauan masyarakat akan pentingnya gotong royong dalam suatu kegiatan pembangunan, juga tingkat pendidikan masyarakat yang rendah maka mereka sulit untuk mengerti apa pentingnya pembangunan yang akan direncanakan dan dilaksanakan. Karena dari ketidaktahuan itulah yang menyebabkan masyarakat memiliki sikap acuh dan bermasa bodoh terhadap pembangunan.

Jadi, peran Lembaga Pemberdayaan Masyarakat sebagai fasilitator melalui LPM kelurahan Mamasa sangat rendah hal ini menunjukkan masyarakat yang kurang aktif dan memiliki kesadaran rendah untuk merencanakan pembangunan hal ini disebabkan dari kurangnya minat masyarakat.

b. Masyarakat Ikut Dalam Merencanakan Prioritas Usulan Program Prioritas usulan yang ingin dibuat harus sesuai dengan kebutuhan masyarakat dan juga mendesak dilaksanakan ditingkat kelurahan.

Di dalam ikut menentukan prioritas usulan yang ingin dibuat merupakan bentuk peran masyarakat yang sangat penting karena masyarakat yang lebih mengetahui pembangunan apa yang dibutuhkan oleh masing-masing kelurahan untuk dilaksanakan. Untuk memperoleh informasi yang jelas maka hal mengenai prioritas penyelenggaraan program pemerintah yang akan dilaksanakan di Kelurahan Mamasa maka hal ini dijelaskan dalam wawancara bersama tokoh masyarakat kelurahan Mamasa bahwa:

"Yang saya lakukan dalam penyelenggaraan prioritas program pembangunan hanya untuk kepentingan masyarakat disini" (Wawancara, 23 Januari 2019)

Berdasarkan hasil wawancara dengan salah seorang informan selaku masyarakat (kepala sekolah) di kelurahan Mamasa bahwa masyarakat yang memiliki rasa peduli dengan kemajuan pembangunan dapat ditunjukkan dengan keikutsertaannya di dalam memberikan usulan program LPM Kelurahan antara lain dengan ikut menentukan prioritas usulan program yang ingin dibuat yaitu dengan hadir ketika rapat diadakan yaitu musrenbang kelurahan Mamasa.

Selanjutnya wawancara dengan pak Lurah yang menyatakan bahwa: 
"Penentuan prioritas dapat dilihat dulu apa yang menjadi kebutuhan masyarakat itu yang diprioritaskan untuk kepentingan bersama dan kemudian melihat apa-apa saja yang sudah diprogramkan oleh pemerintah setelah itu kita sesuaikan dengan yang dibutuhkan oleh masyarakat kelurahan Mamasa. Kemudian program prioritas dalam Lembaga Pemberdayaan Masyarakat memang dilakukan setahun sekali dalam rapat musrenbang ditingkat kelurahan". (Wawancara, 23 Januari 2019)

Berdasarkan hasil wawancara di atas kemudian ditambahkan oleh tokoh masyarakat bahwa:

"Memang program yang dijadikan sebagai prioritas di kelurahan ini sangat dibutuhkan tetapi terkadang masyarakat tidak ada komentar dengan program LPMK, karena sebenarnya LPMK dikelurahan ini kurang berperan disebabkan apabila ada bantuan dari pemerintah dialihkan ke pihak ketiga yaitu kontraktor pihak itulah yang mengerjakan yang seharusnya menjadi kewenangan LPMK mengapa demikian karena disinilah kelemahan ketua LPMK yang diibaratkan tidak bisa menjemput bola dengan baik, dan ketua LPMK itu sendiri tidak proaktif menjemput proyek, dan apabila ada proyek masuk dia tahu bahwa pengelolanya adalah kontraktor bukan organisasinya yang seharusnya menjadi tugas dari organisasinya bahkan dia terima saja tidak mengkritisinya". (Wawancara, 1 Maret 2017)

Berdasarkan hasil wawancara dengan salah seorang informan selaku tokoh masyarakat di kelurahan Mamasa maka diketahui bahwa peran Lembaga Pemberdayaan Masyarakat Kelurahan (LPMK) sebagai fasilitator masih rendah sesuai aturan yang berlaku untuk LPMK hal ini dapat dilihat dari pernyataan ketua Badan Keswadayaan Masyarakat (BKM) yang menyatakan bahwa LPMK di kelurahan Mamasa tidak proaktif dalam pelaksanaan pembangunan di kelurahan Mamasa karena organisasi tersebut tidak mengkritisi atas apa yang menjadi kewenangannya, dan sebagian besar masyarakatnya juga tidak banyak komentar dengan pelaksanaan pembangunan.

2. Lembaga Pemberdayaan Masyarakat Kelurahan sebagai Dinamisator

Dalam mengoptimalkan pelaksanaan pembangunan, LPMK harus teliti dan bijaksana dalam memantau kegiatan pembangunan dengan cara menempatkan dirinya di tengah-tengah masyarakat untuk bisa mendorong masyarakat untuk lebih berperan aktif di masing-masing lingkungan.

a. LPMK Melakukan Pemantauan dan Pengawasan terhadap kegiatan.

Keberhasilan suatu pembangunan yang diinginkan oleh pemerintah adalah terwujudnya program yang telah direncanakan dengan partisipasi secara langsung oleh masyarakat baik dalam pelaksanaan maupun memberikan 
bantuan tenaga, pikiran maupun materi yang bertujuan untuk menyukseskan pembangunan yang dibutuhkan masyarakat kelurahan Mamasa. Maka dari itu LPMK harus melakukan pengawasan atau pemantauan terhadap kegiatan pembangunan agar apa yang dilakukan masyarakat dapat terpantau dengan baik. Maka agar mengetahui sejauh mana LPMK melaksanakan perannya maka dapat dilihat dari informasi yang disampaikan oleh tokoh pemuda bahwa:

"LPM kelurahan Mamasa disini tidak melakukan pemantauan secara bertahap, mereka hanya mengecek disaat awal berjalannya program pembangunan dan setelah selesainya pelaksanaanya program pembangunan tersebut. Setelah selesai proses semua itu sama sekali tidak ada. Maka perannya tidak berjalan maksimal" (Wawancara, 22 Januari 2019)

Berdasarkan hasil wawancara di atas bahwa peran LPMK tidak dilaksanakan secara maksimal karena dilihat dari informasi dari tokoh pemuda bahwa pemantauan yang dilaksanakan hanya diawal dan diakhir penyelesaian pembangunan saja setelah itu sama sekali tidak ada. Dari informasi di atas maka selanjutnya dilakukan wawancara dengan kepala lingkungan yang dimana dalam pelaksanaan pemantauan pembangunan apakah benar tidak dilakukan secara maksimal, maka dikemukakan oleh bapak selaku kepala lingkungan bahwa:

"Pembangunan fisik yang telah dibangun yah berjalan dengan semestinya. Sebagai kepala lingkungan saya belum pernah melihat anggota ataupun ketua LPMK melakukan pemantauan secara langsung jika pembangunan tersebut sudah selesai." (Wawancara, 22 Januari 2019)

Kurang maksimlanya peranan Lembaga Pemberdayaan Masyarakat Kelurahan (LPMK) di Kelurahan Mamasa juga disebabkan karena kurang perhatiaannya pemerintah Kabupaten Bone terhadap Lembaga Pemberdayaan Masyarakat Kelurahan (LPMK) di Kelurahan Mamasa. Hal ini terbukti sampai sekarang Lembaga Pemberdayaan Masyarakat Kelurahan (LPMK) belum berbadan hukum.

Hal ini berdasarkan hasil wawancara dengan Ketua Lembaga Pemberdayaan Masyarakat Kelurahan (LPMK) yang mengatakan bahwa:

"Organisasi Lembaga Pemberdayaan Masyarakat Kelurahan (LPMK) di kelurahan Mamasa ini tidak berbadan hukum, beberapa kali kami melakukan pertemuan di kantor Bupati yang katanya akan diakta notariskan namun pada kenyataannya tidak ada yang dilakukan, maka dari itu peran kami sebagai LPMK masih kurang maksimal (Wawancara, 26 Januari 2019) 
Berdasarkan hasil wawancara diatas dijelaskan bahwa ada beberapa faktor yang menjadi hambatan Lembaga Pemberdayaan Masyarakat Kelurahan (LPMK) dalam melaksanakan perannya di Kelurahan Mamasa salah satunya kurang perhatiaannya pemerintah Kabupaten Bone dengan Lembaga Pemberdayaan Masyarakat Kelurahan (LPMK) ini.

Hal ini disebabkan adanya kepentingan politik yang mendominasi pekerjaan di Kelurahan Mamasa.

Hal ini berdasarkan hasil wawancara dengan ketua Lembaga Pemberdayaan Masyarakat Kelurahan (LPMK) yang mengatakan bahwa:

"Bagaimana lembaga kami bisa berperan dengan semestinya jika program pembangunan yang semestinya dikerjakan oleh pihak kami namun pada kenyataannya dialihkan ke pihak ketiga yaitu kontraktor" (Wawancara, 22 Januari 2019)

Agar terciptanya partisipasi masyarakat dalam pembangunan, maka dibutuhkan komunikasi pembangunan artinya tujuan komunikasi pembangunan bukanlah sekedar untuk memasyarakatkan pembangunan dan menyampaikan pesan-pesan tentang pembangunan saja tetapi yang lebih penting dalam komunikasi pembangunan yaitu menumbuhkan dan menggerakkan partisipasi masyarakat dalam proses pembangunan. Melalui komunikasi pembangunan dapat ditempuh untuk meningkatkan partisipasi masyarakat.

Tipe partisipasi masyarakat menurut (Hobley,1996:204) ada tujuh tipe yaitu: (1)Partisipasi pasif, (2) Partisipasi informative, (3) Partisipasi konsultatif (4) Partisipasi insentif, (5) Partisipasi fungsional, (6) Partisipasi interaktif, (7) Self mobilization (mandiri).

Berdasarkan tipe partisipasi masyarakat di atas bahwa masyarakat di kelurahan Mamasa termasuk pada partisipasi pasif dimana masyarakat diberitahu apa yang sedang atau telah terjadi, masyarakat hanya menunggu informasi dan arahan dari pihak pelaksana.

Tentang hal di atas yang terjadi dalam pelaksanaan pembangunan di kelurahan Mamasa menurut informasi dari Lurah Mamasa yang mengatakan bahwa:

"Dalam hal meningkatkan partisipasi masyarakat dalam pembangunan di kelurahan Mamasa ini sebenarnya peran LPM di kelurahan Mamasa kurang maksimal karena dilihat dari partisipasi masyarakat yang masih kurang keikutsertaannya dalam pelaksanaan pembangunan dan juga apabila ada bantuan dari pemerintah yang masuk selalu dipihak ketigakan yaitu beralih ke kontraktor yang seharusnya menjadi kewenangan dari LPMK dan juga 
LPMK tidak proaktif pada pembangunan. Maka dari itu partisipasi masyarakat di sini masih kurang dan LPM di kelurahan ini kurang berperan sebagaimana mestinya". (Wawancara, 21 Januari 2019)

Adapun pernyataan dari kepala lingkungan kelurahan Mamasa yang menyatakan bahwa :

"Di lingkungan ini beberapa keluhan dari masyarakat terutama untuk masalah MCK umum, disini MCK umumnya tidak ada bahkan ada rumah warga yang tidak memiliki we karena tidak adanya biaya, mereka berharap agar di buatkan MCK umum karena mereka merasa susah apabila mau buang air, malahan kalau mereka mau buang air mereka pergi ke sawah, dan kebutuhan masyarakat disini sampai sekarang belum di laksanakan maka dari itu tugas LPMK di kelurahan Mamasa ini menurut saya sangat kurang berperan sesuai dengan aturan yang ada, karena apabila ada bantuan dari pemerintah yang masuk yang mngerjakannya bukan dari pihak LPMK malahan saya liat kontraktor yang menanganinya yang seharusnya menjadi kewenangan dari LPMK". (wawancara pada tanggal 23 Januari 2019).

Terkait dengan partisipasi masyarakat, ada empat lingkup partisipasi masyarakat dalam pembangunan, yaitu:

1. Partisipasi dalam Pengambilan Keputusan Partisipasi masyarakat dalam pembangunan di wilayahnya perlu ditumbuhkan melalui forum yang memungkinkan masyarakat berpartisipasi langsung dalam proses pengambilan keputusan terhadap program pembangunan di wilayah setempat.

2. Partisipasi dalam Pelaksanaan Pembangunan. Diartikan bahwa dalam pelaksanaan kegiatan pembangunan, perlu adanya pemerataan sumbangan masyarakat dalam bentuk tenaga kerja, uang tunai, dan atau bentuk korbanan lainnya yang sepadan dengan manfaat yang akan diterima oleh masingmasing warga/masyarakat.

3. Partisipasi dalam Pemantauan dan Evaluasi Pembangunan Bentuk partisipasi masyarakat dalam memantau dan mengevaluasi program dan kegiatan pembangunan sangat diperlukan, guna mengetahui apakah tujuan yang dicapai sudah sesuai dengan harapan. Selain itu juga untuk memperoleh umpan balik tentang masalah/kendala yang muncul dalam pelaksanaan pembangunan yang sedang dilaksanakan.

4. Partisipasi dalam Pemanfaatan Hasil Pembangunan Seringkali masyarakat tidak memahami manfaat dari setiap program pembangunan secara langsung, sehingga hasil pembangunan menjadi sia-sia. Dengan demikian, perlu adanya partisipasi masyarakat dengan kemauan dan kesukarelaan untuk memanfaatkan hasil pembangunan, misalnya: memanfaatkan jembatan penyeberangan jalan, dan sebagainya. 
Adapun yang menjadi faktor penghambat kurang maksimalnya peranan LPMK dalam meningkatkan partisipasi masyarakat di kelurahan Mamasa yaitu tidak proaktifnya ketua LPMK terhadap program pembangunan, maka setiap pembangunan yang dilaksanakan yang menanganinya dipihak ketigakan hal ini juga disebabkan kurang bertanggung jawabnya pihak LPMK maka dari itu setiap program pembangunan di alihkan ke kontraktor dan pihak LPMK hanya menerima saja keputusan yang ada.

\section{KESIMPULAN}

Berdasarkan hasil penelitian yang telah dibahas pada bab sebelumnya, maka dapat ditarik kesimpulan bahwa peranan Lembaga Pemberdayaan Masyarakat Kelurahan (LPMK) dalam menampung dan menyalurkan aspirasi masyarakat belum maksimal, hal ini terlihat dari kurang berperannya pihak Lembaga Pemberdayaan Masyarakat Kelurahan (LPMK) dalam menampung dan menyalurkan aspirasi masyarakat. Dimana pihak LPMK tidak menjadwalkan waktu yang tepat untuk mengadakan rapat bersama setiap kepala lingkungan, sehingga tidak efektifnya penyampaian aspirasi yang dilakukan oleh setiap kepala lingkungan kepada LPMK. Peranan Lembaga Pemberdayaan Masyarakat Kelurahan (LPMK) dalam meningkatkan partisipasi masyarakat belum maksimal, hal ini terlihat bahwa LPMK di kelurahan Mamasa tidak proaktif terhadap pembangunan fisik sehingga setiap pelaksanaan program pembangunan fisik di kelurahan Mamasa di pihak ketigakan yaitu dialihkan pada kontraktor yang seharusnya menjadi kewenangan dari LPMK

\section{SARAN}

Berdasarkan kesimpulan di atas, maka sebagai bahan pertimbanagan dikemukakan beberapa saran bagi Lurah, LPMK (Lembaga Pemberdayaan Masyarakat Kelurahan) maupun kepada peneliti selanjutnya, yaitu: peran Lembaga Pemberdayaan Masyarakat Kelurahan (LPMK) dalam menampung dan menyalurkan aspirasi masyarakat di kelurahan Mamasa harus lebih dioptimalkan, agar aspirasi masyarakat dapat dilaksanakan sesuai dengan kebutuhan masyarakat setempat. Peran Lembaga Pemberdayaan Masyarakat Kelurahan (LPMK) dalam meningkatkan partisipasi masyarakat sebagai penggerak dalam pembangunan lebih ditingkatkan dan Lembaga Pemberdayaan Masyarakat Kelurahan (LPMK) harus proktif terhadap pembangunan fisik, agar setiap program pembangunan 
yang dilaksanakan di kelurahan Mamasa masyarakat dapat terlibat aktif.

\section{DAFTAR PUSTAKA}

Aprillia Theresia, Krisnha dkk. 2015. Pembangunan Berbasis Masyarakat.,Alfabeta, Bandung.

Abe, Alexander, 2002, Perencanaan daerah partisipatif, pondok edukasi,Solo

Duverger, Maurice, 1985, Sosiologi Politik, Rajawali, Jakarta.

Kunarjo, 2002, Perencana dan Pengendalian program Pembangunan, penerbit Universitas Indonesia UI Press, Jakarta.

Koenjaraningrat. 1985. Kebudayaan Mentalitas dan Pembangunan. Gramedia. Jakarta.

Riyadi \& Dedy Supriyady Bratakusumah (2004) Perencanaan Pembangunan

Daerah: Strategi Menggali Potensi dalam mewujudkan otonomi daerah, PT Gramedia Pustaka utama Jakarta.

Rauf, Rahyunir \& Munaf, Yusri. 2015. Lembaga Kemasyarakatan Indonesia. Zanafa Publishing, Yogyakarta.

Soekanto, Soerjono, 2003, Sosiologi Suatu Pengantar, Cetakan ke enam,Rajawali Grafindo, Jakarta.

Sumaryadi, Nyoman, I, 2000, Perencanaan Pembangunan Daerah Otonomi dan Pemberdayaan Masyarakat, CV Cita Utama, Jakarta.

Tjokroamidjoyo, Bintaro, 1996, Perencanaan Pembangunan, Gunung Agung, Jakarta. 